\title{
A Parameter Ascertainment Method for the Skeleton Curve of Corroded Reinforcement Concrete Members with Flexure and Compression
}

\author{
G. F. Chen, Y. Z. Zhang $(\mathbb{D}$, and X. J. Zhu \\ Department of Civil Engineering, Harbin Institute of Technology, Weihai 264209, China \\ Correspondence should be addressed to Y.Z. Zhang; zhyz@hit.edu.cn
}

Received 16 November 2017; Accepted 9 January 2018; Published 14 March 2018

Academic Editor: Carlo Santulli

Copyright (c) 2018 G. F. Chen et al. This is an open access article distributed under the Creative Commons Attribution License, which permits unrestricted use, distribution, and reproduction in any medium, provided the original work is properly cited.

\begin{abstract}
This paper presents an effective method of parameter ascertainment for the skeleton curve of corroded compression-bending members to establish its restoring force model. An assumption which considers the skeleton curve of damaged and undamaged members has similar shape is introduced into the fitting process of parameters. Meanwhile, two-dimensional plane section assumption is used to simplify the mathematical model and reduce the computational cost. Several sets of experimental data were compared with the prediction by the method developed in this paper, for its verification. The case studies show that the experimental trends can be captured very well.
\end{abstract}

\section{Introduction}

Reinforced concrete (RC) structures exposed to the aggressive environmental conditions may cause different types of structural damage. For example, wind, waves, corrosive environment, and extreme temperatures all can impact the existing structures. During the entire service life of the RC structure, the continuous penetration of harmful ions induces cracking and spalling of the concrete cover [1-3], degradation of the bond strength [4-7], and decrease of the material strength [8-12]. In seismic-prone regions, the corrosion damage of the structures would reduce their lateral load-resisting capacity in a seismic event significantly [13-16]. Therefore, the assessment of the seismic performance for the deteriorated concrete structures is urgent and important. In particular, for some existing RC structures exposed to aggressive conditions, the evaluation of their safety and serviceability over time under seismic excitations is more and more concerned.

In this paper, our particular attention is the corroded compression-bending members of RC structures subjected to the seismic hazard. Numerous corrosion experiments have shown that the deterioration of concrete durability not only reduces the load carrying capacity, but also causes a shift of the failure mechanism from the ductile to the brittle type in a number of cases [17-19]. However, due to the uncertainties in the corrosion process, strong nonlinearity of structural properties, and complex requirements on the structures for bearing the impending earthquake, it is a difficult task to precisely predict the seismic fragility of deteriorated RC structures. The restoring force model is a simple and effective method which is widely used and accepted in the design process and seismic fragility estimation of reinforced concrete structures. Many experimental tests and theoretical study on the restoring force model have been performed in recent decades [17], in conditions of both artificial corrosion (e.g., $[18,19])$ and no corrosion (e.g., $[20,21])$, and they found that the restoring force model of corroded reinforced concrete bending members and skeleton curve in shape compared with uncorroded members are the similar, but the key parameters of corroded members skeleton curve have not determined. The objective of the present work was to establish the skeleton curve of restoring force model for the corroded reinforcement concrete members under bending and compression and to provide a reliable estimation method to determine the value of parameters in the skeleton curve. 


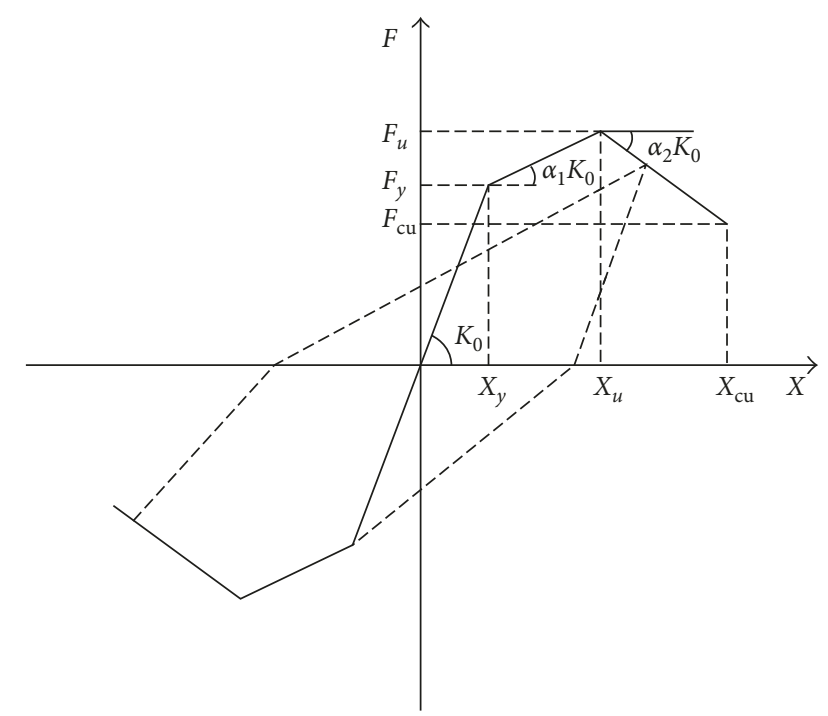

FIGURE 1: The force-restoring model of reinforcement concrete members with flexure and compression.

\section{Review of the Restoring Model of Noncorroded Reinforced Concrete Structure}

Restoring force model contains hysteresis rules and skeleton curve; this paper only discusses the skeleton curve of restoring force model. For shear reinforced concrete structure, the structure of column between the layers is a typical hydraulic member. As shown in Figure 1, the commonly used three linear restoring force models of skeleton curve have a total of six parameters: yield shear force $F_{y}$, yield displacement $X_{y}$, limit shear force $F_{u}$, limit displacement $X_{u}$, collapsing shearing force $F_{\mathrm{cu}}$, and its corresponding displacement $X_{\mathrm{cu}}$. These parameters are influenced by many factors, such as the component's geometry size, shape of cross section, material performance, reinforcement ratio, and axial compression ratio. Most of the research results are based on a large number of repeated load tests, and the skeleton curves are determined by the experimental analysis of data fitting statistics. There is still a lack of unified recognized theoretical formula to determine the skeleton curve of the parameters.

In this paper, the parameter determination of skeleton curve of noncorroded compression-bending members still is used as which of corroded reinforced concrete elements what proposed in the literature [21]. According to the research results, for symmetrical reinforcement of rectangular cross section as shown in Figure 2, the parameters of the restoring force model was evaluated by using Equations (3.1)-(3.12) in the literature [21].

\section{Determination of the Restoring Model for Corroded Reinforced Concrete Structure}

3.1. Extension of the Restoring Force Model for Damaged Members. According to those experimental researches

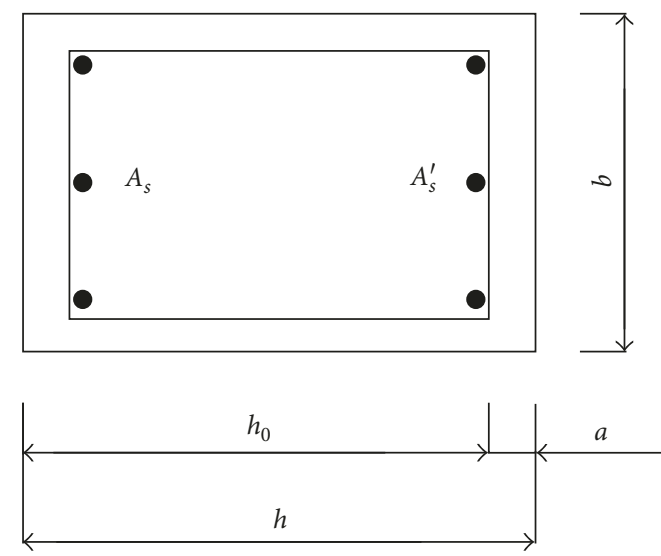

FIgURE 2: Symmetrically reinforced rectangular cross section.

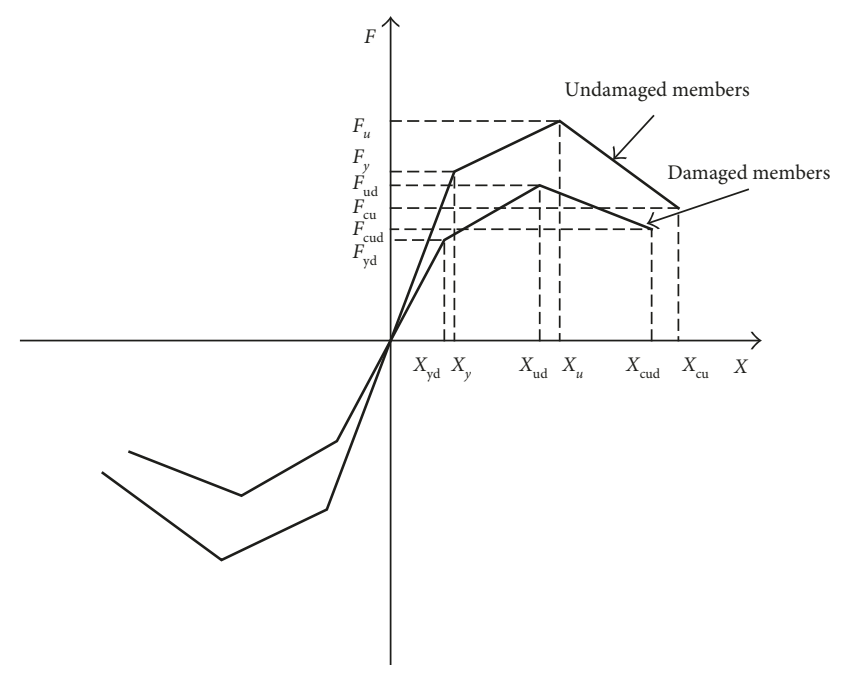

Figure 3: The force-restoring model of corroded reinforcement concrete members with flexure and compression.

$[18,19]$, the restoring force models of corroded reinforced concrete bending members and skeleton curve in shape compared with uncorroded members are similar; therefore, we can think that only the parameters reduced in different damage degrees between the corroded and uncorroded members. In this paper, we used a three-stage skeleton curve model which was presented by Jinping et al. [21] to determine the skeleton curve of the undamaged and damaged members, as shown in Figure 3.

\subsection{Estimation of Parameters}

3.2.1. Yield Shear Force $F_{y}$ and Its Corresponding Displacement $X_{y}$. The yield of corroded members can be still defined as reinforcement yielding or the ultimate compression strain of concrete. One of the most crucial factors affecting the service life of reinforced concrete (RC) structures attacked by aggressive ions is reinforcement corrosion. Corrosion of reinforcing steel produces corrosion products with higher volume than the original steel resulting in cracking of the concrete surrounding the bars. Corrosion leads to 
a reduction in the cross-sectional area of the reinforcing steel (or mass loss) and a loss of bond between the reinforcing steel and the concrete. These will be resulting in cross section deformation of reinforced concrete bending components no longer accord with flat section assumption under the action of repeated loading. But if the assumption of plane section is not correct, the whole analysis process will be very difficult. In this paper, based on the analysis of the reference literature [19], the skeleton curve of corroded reinforced concrete is still based on the flat section assumption. Therefore, the yield moment was determined with the following equation:

$$
\begin{aligned}
M_{\mathrm{yd}}= & A_{\mathrm{sd}} f_{\mathrm{yd}}\left(h_{0}-a\right)+n_{0} b h_{0} f_{\mathrm{cd}}\left(\frac{h}{2}-a\right) \\
& -0.5 \eta_{d} b h_{0} f_{\mathrm{cd}}^{\prime}\left(\frac{1}{3} \eta_{d} h_{0}-a\right) .
\end{aligned}
$$

It can be seen that the difference between (1) and (3.12) is the material parameter values of the steel and concrete. $A_{\mathrm{sd}}$ is the cross section of the corroded reinforcement, $f_{\mathrm{yd}}$ is the yield strength of the corroded reinforcement, $f_{\mathrm{cd}}$ is the axial tensile strength of the corroded concrete, $n_{0}$ is the axial compression ratio of the concrete members, $h_{0}$ is the effective height of section, $b$ and $h$ are the sections of the width and height, respectively, and $f_{\mathrm{cd}}^{\prime}$ is the maximum compressive stress of the corroded concrete which can be estimated with

$$
f_{\mathrm{cd}}^{\prime}=\frac{\eta_{d}}{1-\eta_{d}} \cdot \frac{f_{\mathrm{yd}}}{\alpha_{\mathrm{Ed}}}
$$

where $\eta_{d}$ is the coefficient of height in equivalent compressive region, it can be expressed as

$$
\begin{aligned}
\eta_{d}= & \left\{\left(\rho_{t}+\frac{n_{0}}{\alpha_{\mathrm{fd}}}\right)^{2} \alpha_{\mathrm{Ed}}^{2}+\left[\rho_{t}\left(1+\frac{a}{h_{0}}\right)+\frac{2 n_{0}}{\alpha_{\mathrm{fd}}}\right] \alpha_{\mathrm{Ed}}\right\}^{1 / 2} \\
& -\left(\rho_{t}+\frac{n_{0}}{\alpha_{\mathrm{fd}}}\right) \alpha_{\mathrm{Ed}}
\end{aligned}
$$

where $\rho_{t}$ is the ratio of tension reinforcement, $\alpha_{\mathrm{fd}}=f_{\mathrm{yd}} / f_{\mathrm{cd}}$, and $\alpha_{\mathrm{Ed}}=E_{\mathrm{sd}} / E_{\mathrm{cd}} ; E_{\mathrm{sd}}$ and $E_{\mathrm{cd}}$ are the elastic modulus of the corroded reinforcement and concrete.

Layer yield shear force $F_{\mathrm{yd}}$ and section yield moment $M_{\mathrm{yd}}$ still have the following relations:

$$
F_{\mathrm{yd}}=\frac{2 M_{\mathrm{yd}}}{H},
$$

where $H$ is structure height.

To the actual structure, the shear span ratio of compression-bending member is larger (more than 4); we only consider bending deformation in calculating the yield story drift $x_{\mathrm{yd}}$ :

$$
x_{\mathrm{yd}}=\frac{1}{\left(1-\eta_{d}\right) h_{0}} \cdot \frac{H^{2} f_{\mathrm{yd}}}{6 E_{\mathrm{sd}}} .
$$

3.2.2. Limit Shear Force $F_{\mathrm{ud}}$ and Its Corresponding Displacement $X_{\text {ud }}$. A very limited number of research programs have been conducted for corroded reinforced concrete flexural members in the laboratory. In this paper, we assume that the limit shear force $F_{\mathrm{ud}}$ components and the limit displacement $X_{\mathrm{ud}}$ of the damaged members still meet the statistical analysis of undamaged components.

$$
\begin{aligned}
F_{\mathrm{ud}} & =\left(1.24-0.075 \rho_{t} \alpha_{\mathrm{fd}}-0.5 n_{0}\right) F_{\mathrm{yd}}, \\
X_{\mathrm{ud}} & =\mu_{\mathrm{ud}} X_{\mathrm{yd}},
\end{aligned}
$$

where $\mu_{\text {ud }}$ is the ductility coefficient of its corresponding limit shear force $F_{\text {ud }}$, which can be obtained from

$$
\mu_{\mathrm{ud}}=\frac{\sqrt{1+6 \alpha_{w} \lambda_{w}}}{\left(0.045+1.75 n_{0}\right)},
$$

where $\lambda_{w}=\rho_{w} \alpha_{\mathrm{fd}}$ is the stirrup restraint coefficient, $\rho_{w}$ is volume stirrup ratio, and $\alpha_{w}$ is the coefficient associated with stirrup forms; $\alpha_{w}$ for ordinary stirrup, spiral stirrup, and composite stirrup is $1.0,2.05$, and 3.0 , respectively.

\subsubsection{Collapsing Shearing Force $F_{\text {cud }}$ and Its Corresponding} Displacement $X_{\text {cud }}$. In the present work, the destruction of the damaged reinforced concrete bending member still defined as limit shear force is $85 \%$ [21]:

$$
F_{\text {cud }}=0.85 F_{\text {ud }} \text {. }
$$

The collapsing displacement $X_{\text {cud }}$ is adopted in this study:

$$
X_{\text {cud }}=\mu_{\text {cud }} x_{\text {yd }},
$$

where ductility coefficient can be estimated by (11) when limited shear $F_{\mathrm{ud}}$ is $90 \%$.

$$
\mu_{\mathrm{cud}}^{\prime}=\frac{\sqrt{1+30 \alpha_{w} \lambda_{w}}}{\left(0.045+1.75 n_{0}\right)} .
$$

After geometric conversion, $\mu_{\text {cud }}$ can be obtained:

$$
\mu_{\text {cud }}=1.5 \mu_{\text {cud }}^{\prime}-0.5 \mu_{\text {ud }} \text {. }
$$

According to (1-12), we can determine the six parameters of skeleton curve of corroded compression-bending members. The difference of skeleton curve of the damaged and undamaged members is that they have the different the material parameters.

\subsection{Determination of Material Degradation Index}

3.3.1. Corroded Reinforcement. In this study, the physical and mechanical performance indexes of the corroded reinforcements are the cross section area $A_{\text {sd }}$, the yield strength $f_{\mathrm{yd}}$, and the elastic modulus $E_{\mathrm{sd}}$.

The current evaluation of rebar corrosion degree mostly uses mass loss ratio or area loss ratio; in this work, we adopted the researcher Y.L.Hui's [22] results in which she investigated the relationship of area loss and mass loss by a large number of experimental research and microstructure analysis, as shown in Table 1.

The yield strength $f_{\mathrm{yd}}$ of the corroded reinforcement can be estimated by 
TABLE 1: The relationship of area loss and mass loss.

\begin{tabular}{lc}
\hline Mass loss ratio & $\begin{array}{r}\text { The relationship of mass loss ratio } \\
\rho \text { and area loss ratio } \rho_{s}\end{array}$ \\
\hline Less than $10 \%$ & $\rho_{s}=0.013+0.987 \rho$ \\
$10 \% \sim 20 \%$ & $\rho_{s}=0.061+0.939 \rho$ \\
$20 \% \sim 30 \%$ & $\rho_{s}=0.129+0.871 \rho$ \\
$30 \% \sim 40 \%$ & $\rho_{s}=0.199+0.801 \rho$ \\
\hline
\end{tabular}

$$
f_{\text {yd }}=\frac{0.985-1.208 \rho_{s}}{1-\rho_{s}} f_{y} .
$$

Lee et al. [23] reported the equation of the elastic modulus of corroded reinforcement by a large of experimental programs which considered the influence of the elastic modulus of the uniform and the pit corrosion, for uniform corrosion, $E_{\mathrm{sd}}=(1-0.75 \rho / 100) E_{s}$, but for pit corrosion, $E_{\mathrm{sd}}=(1-1.13 \rho / 100) E_{s}$, where $E_{s}$ and $E_{\mathrm{sd}}$ are the elastic modulus of noncorroded and corroded reinforcement and $\rho$ is the corrosion level of the steel reinforcement which was determined using the mass loss analysis described.

3.3.2. Concrete with Corrosion-Induced Damage. Compared with the undamaged members, the damaged concrete bending members involved in the concrete mechanical properties change have two parameters: the axial compressive strength and elastic modulus of concrete. Considerable research work has been carried out on the effect of corrosion on the mechanical properties of concrete; there have been several studies [24-27] that tried to correlate the effect of corrosion on the load capacity of corroded reinforced concrete elements; however, there have not been a universally recognized conclusion to correlate the results from these pre- and postcorrosion methods where the data can be used to predict the safety of concrete structure based on corrosion level. In the present investigation, the effect of the steel manufacturing method upon the performance of reinforcing concrete bars against atmospheric corrosion is studied. Because of the limitations of the currently available data on corrosion level, a study that can resolve these difficulties is needed to better predict the safety of aged concrete structures due to corrosion. Moreover, a number of studies have been carried out on corrosion of reinforced concrete bending members under repeated loading in the laboratory by accelerated corrosion test, which uses electrochemical method to accelerate the reinforcement corrosion; most of the test does ignore the deterioration of concrete; Therefore, in this paper, the mechanical performance index of the corroded concrete is used as follows: the mechanical performance index of undamaged concrete is applied when the test data are absent; otherwise, the real test data are used.

\section{Verification}

The following selected test instances were to be calculated to validate the effectiveness of the proposed parameters which

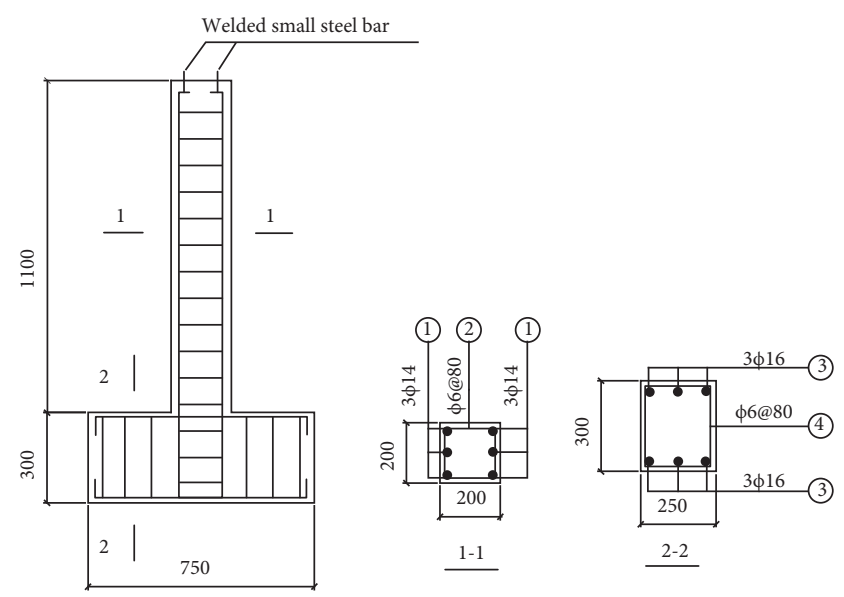

FIGURE 4: Details of test specimen (unit: mm).

determine the skeleton curve of the force-restoring model of corroded reinforced concrete members with flexure and compression.

\subsection{Case 1}

4.1.1. Description of Experiment. This example comes from the literature [20], which did experimental study on the corroded reinforced concrete bending member restoring force performance in 1999. The specimen for rectangular symmetric reinforcement section is suitable for the conditions of the formula are presented. Two series of tests were conducted: six corroded specimens and one uncorroded member. C25 concrete was applied to design the specimen. The column specimens were cast by ordinary Portland cement, and its water-cement ratio is 0.55 . Figure 4 illustrates the column specimen geometry and reinforcement layout. All specimens were reinforced with six longitudinal deformed steel reinforcing bars of diameter $14 \mathrm{~mm}$ and hoop steel reinforcing bars of diameter $6 \mathrm{~mm}$, resulting in a longitudinal reinforcement ratio (total area of longitudinal reinforcement divided by gross section area) of $1.355 \%$. And cubes were cast along with the specimens, and the mean cubic concrete compressive strength at 28 days was 31.1 MPa.

An external current method [15] was utilized to induce corrosion in the specimens. The specimens were immersed in a water tank containing $3 \%-5 \% \mathrm{NaCl}$ solution. The actual corrosion level, also known as corrosion loss, was accordingly measured as the loss in weight of steel bar relative to the weight before corroding, thereby representing an average corrosion level. The measured mass loss ratios of corroded steel corresponding to different corrosion levels and the yield strength of corroded steel bar are given in Table 2 .

All the columns were tested under combined constant axial load and reversed cyclic lateral force in a testing frame, as shown in Figure 5. A constant axial load was applied first using hydraulic loading equipment to simulate the dead load on the column. The axial compression ratio of columns is about 0.27 . The reversed cyclic lateral load was then applied through two one-way hydraulic jacks and measured by two 
TABLE 2: Mass loss rate and the yield strength of corrosion steel bar.

\begin{tabular}{|c|c|c|c|c|c|c|c|}
\hline Number of specimens & ZZ-1 & $\mathrm{Z}-2$ & $\mathrm{Z}-3$ & Z-4 & Z-5 & Z-6 & $\mathrm{Z}-7$ \\
\hline Mass loss rate & $0 \%$ & $20 \%$ & $18 \%$ & $18 \%$ & $23 \%$ & $6 \%$ & $25 \%$ \\
\hline Yield strength/MPa & 415.6 & 413.7 & 415.4 & 413.3 & 404.0 & 408.2 & 395.8 \\
\hline
\end{tabular}

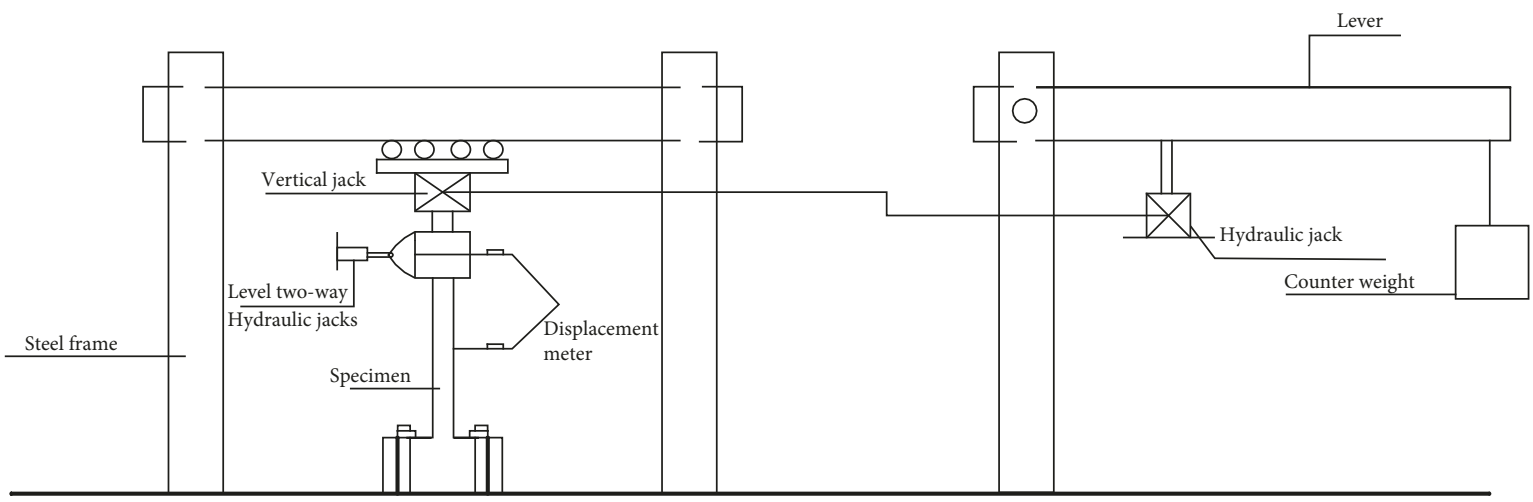

FIgURE 5: Loading device.

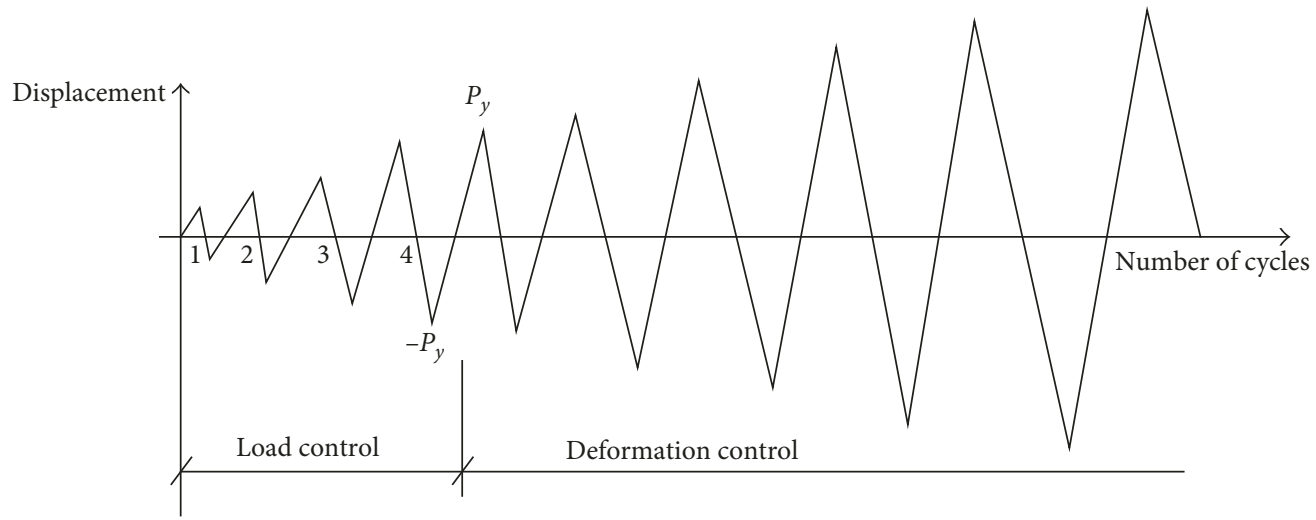

Figure 6: Lateral displacement history.

load cells attached to the hydraulic jacks. Two electronic displacement meters were used to measure the cyclic lateral displacement at the top of the effective length of the column. Cracks were marked, measured, and photographed at each lateral displacement amplitude. Readings of forces and displacements from load cells and electronic displacement meters were recorded throughout the loading. As shown in Figure 6, the cyclic load was exerted on a load-displacement control basis; the horizontal load is applied first until the specimen reaches the yield load, then the displacement control loading is used, and three full cycles were applied at each displacement using a triangular waveform. All the instruments were connected to an automatic data acquisition system and a computer.

In this paper, the test yield shear force of the specimens, the yield displacement, ultimate shear, limit displacement, the collapsing shear force and its corresponding displacement, and so on six parameters were calculated, by the proposed approach of the skeleton curve parameter determination of corroded compression-bending members restoring force model. The numerical and experimental results are shown in Tables 3-5.

\subsubsection{Comparison of the Results Obtained by Experiment and Our Model}

(1) The yield shear force $F_{y}$ and its corresponding displacement $X_{y}$ of the damaged members

As shown in Table 3, at the same axial compression ratio of different degrees of corrosion reinforced concrete member, the calculated yield shear force value agrees well with the experiment result. But for the yield displacement of the specimen Z-2 and Z-4, the ratio between the calculated value and the experiment result is slightly larger. The reasons may be as follows: (a) the definition of rebar corrosion rate-uniform corrosion often assumes general. In the actual engineering projects, pitting corrosion is common in reinforcing steel bars, and usually the adopted steel mass loss and section loss rates ignore spatial variability of pitting along a reinforcing bar. As a result, even if it have been 
TABLE 3: The comparison between theoretical value and experimental value.

\begin{tabular}{|c|c|c|c|c|c|c|c|c|}
\hline $\begin{array}{l}\text { Number of } \\
\text { specimens }\end{array}$ & $\begin{array}{c}\text { Axial compression } \\
\text { ratio }\end{array}$ & $\begin{array}{c}\text { Corrosion } \\
\text { rate }(\%)\end{array}$ & $\begin{array}{c}\text { Experimental } \\
\text { value }\left(F_{\mathrm{yd}} / \mathrm{kN}\right)\end{array}$ & $\begin{array}{c}\text { Calculation } \\
\text { value }\left(F_{\mathrm{yd}} / \mathrm{kN}\right)\end{array}$ & Ratio & $\begin{array}{c}\text { Experimental value } \\
\left(X_{\mathrm{yd}} / \mathrm{mm}\right)\end{array}$ & $\begin{array}{c}\text { Calculation value } \\
\left(X_{\mathrm{yd}} / \mathrm{mm}\right)\end{array}$ & Ratio \\
\hline ZZ-1 & 0.27 & 0 & 41.78 & 47.70 & 1.14 & 9.32 & 10.37 & 1.11 \\
\hline $\mathrm{Z}-2$ & 0.27 & 20 & 38.51 & 37.24 & 0.97 & 7.08 & 9.81 & 1.39 \\
\hline $\mathrm{Z}-3$ & 0.27 & 18 & 37.11 & 38.06 & 1.03 & 7.85 & 9.87 & 1.26 \\
\hline $\mathrm{Z}-4$ & 0.27 & 18 & 36.31 & 38.06 & 1.05 & 6.79 & 9.87 & 1.45 \\
\hline $\mathrm{Z}-5$ & 0.27 & 23 & 31.34 & 33.72 & 1.08 & 8.03 & 9.52 & 1.19 \\
\hline Z-6 & 0.27 & 6 & 41.15 & 44.91 & 1.09 & 9.36 & 10.27 & 1.09 \\
\hline $\mathrm{Z}-7$ & 0.27 & 25 & 36.89 & 32.96 & 0.89 & 9.03 & 9.44 & 1.05 \\
\hline
\end{tabular}

Note: ratio = calculation value/experimental value, the ratio in the following table are calculated according to this definition.

TABLE 4: The comparison between theoretical value and experimental value.

\begin{tabular}{|c|c|c|c|c|c|c|c|c|}
\hline $\begin{array}{l}\text { Number of } \\
\text { specimens }\end{array}$ & $\begin{array}{c}\text { Axial compression } \\
\text { ratio }\end{array}$ & $\begin{array}{l}\text { Corrosion } \\
\text { rate }(\%)\end{array}$ & $\begin{array}{c}\text { Experimental } \\
\text { value }\left(F_{\mathrm{ud}} / \mathrm{kN}\right)\end{array}$ & $\begin{array}{c}\text { Calculation } \\
\text { value }\left(F_{\mathrm{ud}} / \mathrm{kN}\right)\end{array}$ & Ratio & $\begin{array}{c}\text { Experimental } \\
\text { value }\left(X_{\mathrm{ud}} / \mathrm{mm}\right)\end{array}$ & $\begin{array}{c}\text { Calculation value } \\
\left(X_{\mathrm{ud}} / \mathrm{mm}\right)\end{array}$ & Ratio \\
\hline ZZ-1 & 0.27 & 0 & 50.15 & 52.65 & 1.05 & 22.54 & 21.07 & 0.94 \\
\hline $\mathrm{Z}-2$ & 0.27 & 20 & 45.79 & 41.10 & 0.90 & 13.20 & 19.86 & 1.50 \\
\hline Z-3 & 0.27 & 18 & 43.54 & 42.01 & 0.96 & 14.32 & 19.98 & 1.40 \\
\hline $\mathrm{Z}-4$ & 0.27 & 18 & 42.27 & 42.01 & 0.99 & 13.22 & 19.98 & 1.51 \\
\hline Z-5 & 0.27 & 23 & 37.01 & 37.23 & 1.01 & 15.20 & 19.23 & 1.27 \\
\hline Z-6 & 0.27 & 6 & 49.65 & 49.57 & 1.00 & 22.37 & 20.84 & 0.93 \\
\hline $\mathrm{Z}-7$ & 0.27 & 25 & 44.37 & 36.38 & 0.82 & 15.62 & 19.07 & 1.22 \\
\hline
\end{tabular}

TABLE 5: The comparison between theoretical value and experimental value.

\begin{tabular}{|c|c|c|c|c|c|c|c|c|}
\hline $\begin{array}{l}\text { Number of } \\
\text { specimens }\end{array}$ & $\begin{array}{l}\text { Axial compression } \\
\text { ratio } \\
\end{array}$ & $\begin{array}{l}\text { Corrosion } \\
\text { rate }(\%)\end{array}$ & $\begin{array}{c}\text { Experimental } \\
\text { value }\left(F_{\text {cud }} / \mathrm{kN}\right) \\
\end{array}$ & $\begin{array}{c}\text { Calculation } \\
\text { value }\left(F_{\text {cud }} / \mathrm{kN}\right) \\
\end{array}$ & Ratio & $\begin{array}{c}\text { Experimental } \\
\text { value }\left(X_{\text {cud }} / \mathrm{mm}\right)\end{array}$ & $\begin{array}{l}\text { Calculation value } \\
\left(X_{\text {cud }} / \mathrm{mm}\right)\end{array}$ & Ratio \\
\hline ZZ-1 & 0.27 & 0 & 42.63 & 44.75 & 1.05 & 41.54 & 26.66 & 0.64 \\
\hline $\mathrm{Z}-2$ & 0.27 & 20 & 38.92 & 34.94 & 0.90 & 28.02 & 24.73 & 0.88 \\
\hline Z-3 & 0.27 & 18 & 37.01 & 35.71 & 0.97 & 24.10 & 24.92 & 1.03 \\
\hline Z-4 & 0.27 & 18 & 35.93 & 35.71 & 0.99 & 23.61 & 24.92 & 1.06 \\
\hline Z-5 & 0.27 & 23 & 34.42 & 31.64 & 0.92 & 19.12 & 23.79 & 1.24 \\
\hline Z-6 & 0.27 & 6 & 42.20 & 42.13 & 1.00 & 39.51 & 26.22 & 0.66 \\
\hline $\mathrm{Z}-7$ & 0.27 & 25 & 37.71 & 30.93 & 0.82 & 19.24 & 23.56 & 1.22 \\
\hline
\end{tabular}

defined as the same corrosion rate, mechanical properties of the member and its index also showed a larger difference, such as test specimen yield displacement of Z-3 and Z-4. (b) experimental error-reinforced concrete is composed of the two materials. Concrete material itself has a large discreteness. As a result, even if the specimens have the same size in the same conditions, its mechanical performance is different. As the literature [20] points out, due to steel corrosion by electrochemical method, there are some differences between corrosion product and reinforced natural rust corrosion products on the morphology and microstructure. Reinforcement corrosion product makes small little cracks of the concrete surface along the longitudinal reinforcement, which is the difference in practical engineering. To some extent, these deficiencies all have great influence in the mechanical properties of concrete members, such as the bigger corrosion rate specimen Z-2 whose yield shear and yield displacement are greater the smaller corrosion rate one Z-3's. (c) the yield point value-the choice of the yield point of test members is a complex problem, and there is no uniform standard. In the literature [20], the yield point is the realistic elastic-plastic yield displacement. But in this paper, the yield displacement of damaged components is calculated. (d) hypothetical formula-in the literature [20], test components corrosion rate is larger, and the bond between the reinforcing steel and the concrete performance loss has been done. In this paper the formula, not considering the change of the bonding property, is still based on the flat section assumption formula established.

(2) The limit shear force $F_{\mathrm{ud}}$ and its corresponding displacement $X_{\mathrm{ud}}$ of the damaged members

It can be seen from Table 4 , the limit shear calculation results agree well with the test value. Similar with Table 3 , the specimens $(Z-2,3,4)$ limit displacement ratio is bigger. In addition to three kinds of reasons ( $, b, c)$ analyzed in Table 3, the reasons for this situation may be the following. At present, few experiment research of corroded compression-bending 


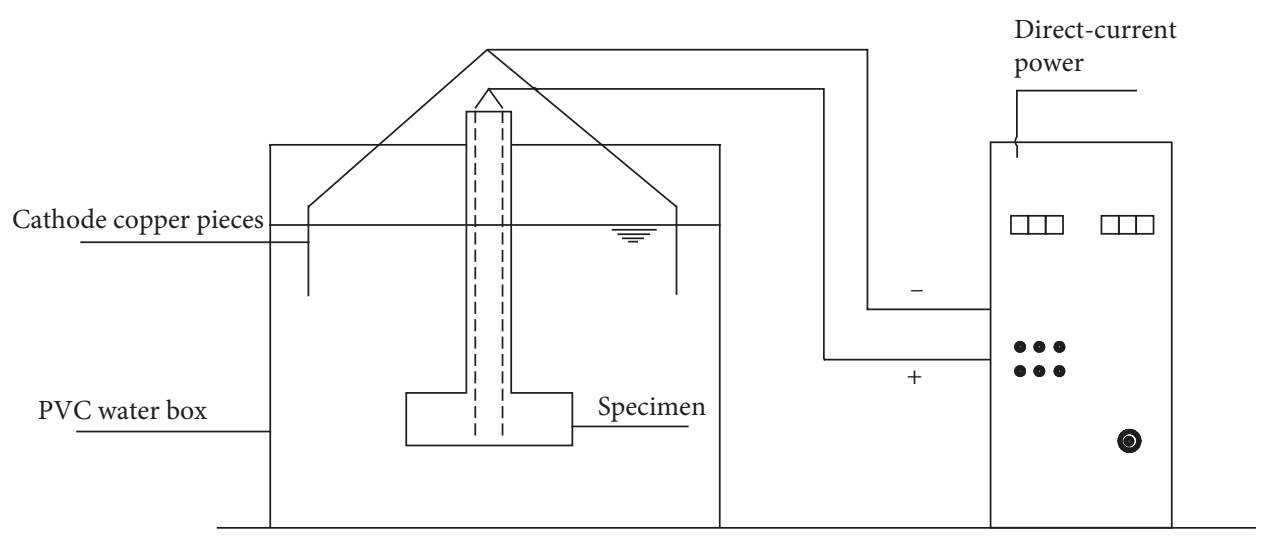

FiguRE 7: Corrosion test device diagram.

TABLE 6: The comparison between theoretical value and experimental value.

\begin{tabular}{|c|c|c|c|c|c|c|c|c|}
\hline $\begin{array}{l}\text { Number of } \\
\text { specimens }\end{array}$ & $\begin{array}{l}\text { Axial compression } \\
\text { ratio }\end{array}$ & $\begin{array}{l}\text { Corrosion } \\
\text { rate }(\%)\end{array}$ & $\begin{array}{c}\text { Experimental } \\
\text { value }\left(F_{\mathrm{ud}} / \mathrm{kN}\right)\end{array}$ & $\begin{array}{c}\text { Calculation } \\
\text { value }\left(F_{\mathrm{ud}} / \mathrm{kN}\right)\end{array}$ & Ratio & $\begin{array}{c}\text { Experimental value } \\
\left(X_{\mathrm{ud}} / \mathrm{mm}\right)\end{array}$ & $\begin{array}{c}\text { Calculation value } \\
\left(X_{\mathrm{ud}} / \mathrm{mm}\right)\end{array}$ & Ratio \\
\hline $\mathrm{XZ}-7$ & 0.2 & 4.06 & 44.32 & 48.58 & 1.09 & 23.23 & 25.73 & 1.11 \\
\hline $\mathrm{XZ}-8$ & 0.2 & 5.87 & 42.45 & 47.70 & 1.12 & 16.85 & 25.64 & 1.52 \\
\hline $\mathrm{XZ}-9$ & 0.2 & 6.56 & 41.66 & 47.36 & 1.14 & 21.71 & 25.60 & 1.18 \\
\hline $\mathrm{XZ}-5$ & 0.4 & 4.23 & 51.30 & 53.13 & 1.04 & 20.40 & 16.02 & 0.79 \\
\hline $\mathrm{XZ}-10$ & 0.4 & 5.87 & 55.73 & 52.39 & 0.94 & 20.70 & 15.97 & 0.77 \\
\hline $\mathrm{XZ}-1$ & 0.4 & 7.64 & 49.50 & 51.60 & 1.04 & 19.75 & 15.92 & 0.81 \\
\hline
\end{tabular}

TABLE 7: The comparison between theoretical value and experimental value.

\begin{tabular}{|c|c|c|c|c|c|c|c|c|}
\hline $\begin{array}{l}\text { Number of } \\
\text { specimens }\end{array}$ & $\begin{array}{l}\text { Axial compression } \\
\text { ratio }\end{array}$ & $\begin{array}{l}\text { Corrosion } \\
\text { rate }(\%)\end{array}$ & $\begin{array}{c}\text { Experimental } \\
\text { value }\left(F_{\mathrm{yd}} / \mathrm{kN}\right)\end{array}$ & $\begin{array}{c}\text { Calculation } \\
\text { value }\left(F_{\mathrm{yd}} / \mathrm{kN}\right)\end{array}$ & Ratio & $\begin{array}{l}\text { Experimental value } \\
\left(X_{\mathrm{yd}} / \mathrm{mm}\right)\end{array}$ & $\begin{array}{l}\text { Calculation value } \\
\qquad\left(X_{\mathrm{yd}} / \mathrm{mm}\right)\end{array}$ & Ratio \\
\hline $\mathrm{XZ}-7$ & 0.2 & 4.06 & 38.43 & 42.66 & 1.11 & 13.42 & 9.68 & 0.72 \\
\hline $\mathrm{XZ}-8$ & 0.2 & 5.87 & 36.08 & 41.89 & 1.16 & 10.12 & 9.64 & 0.95 \\
\hline XZ-9 & 0.2 & 6.56 & 35.94 & 41.59 & 1.16 & 9.91 & 9.63 & 0.97 \\
\hline$X Z-5$ & 0.4 & 4.23 & 44.45 & 51.15 & 1.15 & 12.04 & 11.36 & 0.94 \\
\hline $\mathrm{XZ}-10$ & 0.4 & 5.87 & 46.31 & 50.44 & 1.09 & 10.77 & 14.16 & 1.31 \\
\hline $\mathrm{XZ}-1$ & 0.4 & 7.64 & 42.05 & 49.68 & 1.18 & 10.84 & 13.62 & 1.25 \\
\hline
\end{tabular}

TABle 8: The comparison between theoretical value and experimental value.

\begin{tabular}{|c|c|c|c|c|c|c|c|c|}
\hline $\begin{array}{l}\text { Number of } \\
\text { specimens }\end{array}$ & $\begin{array}{c}\text { Axial compression } \\
\text { ratio }\end{array}$ & $\begin{array}{c}\text { Corrosion } \\
\text { rate }(\%) \\
\end{array}$ & $\begin{array}{c}\text { Experimental } \\
\text { value }\left(F_{\text {cud }} / \mathrm{kN}\right) \\
\end{array}$ & $\begin{array}{c}\text { Calculation } \\
\text { value }\left(F_{\text {cud }} / \mathrm{kN}\right)\end{array}$ & Ratio & $\begin{array}{l}\text { Experimental value } \\
\left(X_{\text {cud }} / \mathrm{mm}\right)\end{array}$ & $\begin{array}{c}\text { Calculation value } \\
\left(X_{\text {cud }} / \mathrm{mm}\right)\end{array}$ & Ratio \\
\hline $\mathrm{XZ}-7$ & 0.2 & 4.06 & 37.67 & 41.29 & 1.04 & 55.39 & 32.44 & 0.59 \\
\hline $\mathrm{XZ}-8$ & 0.2 & 5.87 & 36.09 & 40.54 & 1.12 & 47.18 & 32.25 & 0.68 \\
\hline XZ-9 & 0.2 & 6.56 & 37.62 & 40.26 & 1.07 & 42.02 & 32.20 & 0.77 \\
\hline$X Z-5$ & 0.4 & 4.23 & 43.61 & 45.16 & 1.05 & 36.36 & 20.18 & 0.56 \\
\hline $\mathrm{XZ}-10$ & 0.4 & 5.87 & 47.37 & 44.54 & 0.94 & 29.59 & 20.10 & 0.68 \\
\hline $\mathrm{XZ}-1$ & 0.4 & 7.64 & 42.07 & 43.86 & 1.04 & 32.52 & 20.01 & 0.62 \\
\hline
\end{tabular}

Collapsing shear force $F_{\text {cud }}$ and its corresponding displacement $X_{\text {cud }}$ of the damaged members.

members under the action of repeated loading has been carried out, which leads to difficulty in statistically analyzing the corrosive environment limit displacement test results. At the same time, in the practical engineering and experiment, concrete member stirrup corrosion is more serious than longitudinal reinforcement, especially in the stirrups and longitudinal reinforcement junction. This will directly lead to restriction in stirrup of longitudinal reinforcement and concrete reducing greatly. Limit displacement formula in this paper is reference to the ductility coefficient from intact members' test results of statistical analysis to calculate. This will affect the calculation accuracy. 
(3) The collapsing shearing force $F_{\text {cud }}$ and its corresponding displacement $X_{\text {cud }}$ of the damaged members

The calculated results of the test collapsing shearing force and its corresponding displacement are listed in Table 5. It can be seen that the calculated value of shear force is close to the test value, but its corresponding displacement is deviated. In addition to the reasons listed in Tables 3 and 4, the ductility coefficient used to calculate the collapsing displacement might also be associated.

\subsection{Case 2}

4.2.1. Description of Experiment. This case was presented by N. D. Tao group [28] who has done another group of corroded reinforced concrete seismic performance test under repeated load component in 2002. The differences between this test and the 1999's are as follows:

(1) Experimental simulation is relatively close to actual engineering. In order to simulate the corrosion in actual engineering, first, the specimens were exposed outdoors for 2 years and 6 months, second, the specimens were immersed in a water tank containing $3 \% \sim 5 \% \mathrm{NaCl}$ solution, an external current method was utilized to induce corrosion (Figure 7), and then the external current corroded specimens were put into the open-air pool, and they experienced the drying-wetting alternation cycles (seven days dry, seven days wet). The corrosion test is finished when the obvious corrosion crack is found.

(2) In order to study the effect of axial compression ratio on the seismic performance of corroded members, three axial compression ratios $(n=0,0.2,0.4)$ are considered in this test.

(3) Reinforcement corrosion rate between $4.06 \%$ $8.96 \%$.

(4) The failure mode of the members is bending failure.

Six parameters were calculated by the method described in this paper. The comparison between the calculation results and the test results is shown in Tables 6 and 7 .

4.2.2. Comparison of the Results Obtained by Experiment and Our Model. It can be seen from Table 7 the calculated results of the yield shear force and its corresponding displacement for corroded specimens agreed well with the test results. It can be seen from the calculation results the yield displacement of this paper formula is sensitive to the axial compression ratio. For example, at the same corrosion rate, the value of XZ-8 and XZ-10 with different axial pressure ratios changed significantly. Under the axial pressure ratio, the yield displacement has little influence with the corrosion rate, such as XZ-7, XZ-8, and XZ-9. But this conclusion still needs more tests to verify its correctness.

From Tables 6 and 8, the calculation results of the limit shear force and collapsing shear force have good agreement with the test results, but there was big deviation on limit displacement and collapsing displacement. The possible reasons in addition to those mentioned in Case 1 may be the form of displacement statistics did not conform to the undamaged specimens'.

\section{Conclusion}

The parameter determination method of skeleton curve for corroded specimen was proposed in this paper according to the skeleton curves of undamaged member. The model was verified through test example, and conclusions can be made as follows:

(1) The restoring force model of corroded reinforced concrete bending members and skeleton curve in shape compared with uncorroded members are the similar. It can be considered that their parameters reduced in different damage degrees between the corroded and uncorroded members.

(2) For the yield shear force, the limit shear force, and the collapsing shear force of the proposed model, calculation results have good agreement with the test results, while it was different for the yield displacement, the limit displacement, and the collapsing displacement. And the possible causes of are discussed in this paper.

(3) Due to the lack of experiment research on the restoring force model for the damaged structure, something should be done to further improve the established model to make the theory model more close to actual situation.

\section{Conflicts of Interest}

The authors declare that they have no conflicts of interest.

\section{Acknowledgments}

This work was financially supported by the National Natural Science Foundation of China (51208155 and 51308166) and Weihai Science and Technology Development Plan Project (2013DXGJ08 and 2015DXGJMS011). And this project was also supported by Natural Scientific Research Innovation Foundation in Harbin Institute of Technology (HIT. NSRIF.2015119).

\section{References}

[1] C. Andrade, C. Alonso, and F. Molina, "Cover cracking as a function of bar corrosion: Part I-experimental test," Materials and Structures, vol. 26, no. 8, pp. 453-464, 1993.

[2] X. G. Zhang, M. H. Li, L. P. Tang et al., "Corrosion induced stress field and cracking time of reinforced concrete with initial defects: Analytical modeling and experimental investigation," Corrosion Science, vol. 120, no. 15, pp. 158-170, 2017.

[3] Y. L. Zhang and R. K. Leung Su, "Concrete cover tensile capacity of corroded reinforced concrete," Construction and Building Materials, vol. 136, pp. 57-64, 2017. 
[4] K. Lundgren, "Effect of corrosion on the bond between steel and concrete: an overview," Magazine of Concrete Research, vol. 59, no. 6, pp. 447-461, 2007.

[5] X. H. Wang and X. L. Liu, "Bond strength modeling for corroded reinforcements," Construction and Building Materials, vol. 20, no. 3, pp. 177-186, 2006.

[6] G. Xu, J. Wei, K. Zhang, and X. Zhou, "A calculation model for corrosion cracking in RC structures," Journal of China University of Geosciences, vol. 18, no. 1, pp. 85-89, 2007.

[7] B. Juraj and H. Ivan, "Effect of reinforcement corrosion on bond behavior," Procedia Engineering, vol. 65, pp. 248-253, 2013.

[8] C. Q. Li, J. J. Zheng, W. Lawanwisut, and R. E. Melchers, "Concrete delamination caused by steel reinforcement corrosion," Journal of Materials in Civil Engineering, vol. 19, no. 7, pp. 591-600, 2007.

[9] Y. F. Fan, Z. Q. Hu, Y. Z. Zhang, and J. L. Liu, "Deterioration of compressive property of concrete under simulated acid rain environment," Construction and Building Materials, vol. 24, no. 10, pp. 1975-1983, 2010.

[10] M. C. Chen, K. Wang, and L. Xie, "Deterioration mechanism of cementitious materials under acid rain attack," Engineering Failure Analysis, vol. 27, pp. 272-285, 2013.

[11] S. Imperatore, Z. Rinaldi, and C. Drago, "Degradation relationships for the mechanical properties of corroded steel rebars," Construction and Building Materials, vol. 148, pp. 219-230, 2017.

[12] A. A. Almusallam, "Effect of degree of corrosion on the properties of reinforcing steel bars," Construction and Building Materials, vol. 15, no. 8, pp. 361-368, 2001.

[13] L. Berto, A. Saetta, and P. Simioni, "Structural risk assessment of corroding RC structures under seismic excitation," Construction and Building Materials, vol. 30, pp. 803-813, 2012.

[14] W. Yuan, A. X. Guo, and H. Li, "Seismic failure mode of coastal bridge piers considering the effects of corrosioninduced damage," Soil Dynamics and Earthquake Engineering, vol. 93, pp. 135-146, 2017.

[15] Y. C. Ou, H. D. Fan, and N. D. Nguyen, "Long-term seismic performance of reinforced concrete bridges under steel reinforcement corrosion due to chloride attack," Earthquake Engineering and Structure Dynamics, vol. 42, no. 14, pp. 2113-2127, 2013.

[16] S. H. Xu, A. B. Li, Z. Y. Ji, and Y. Wang, "Seismic performance of reinforced concrete columns after freeze-thaw cycles," Construction and Building Materials, vol. 102, no. 15, pp. 861-871, 2016.

[17] M. Saiidi, "Hysteresis models for reinforced concrete," Journal of Structural Division, vol. 108, no. 5, pp. 1077-1087, 1982.

[18] X. X. Chen, D. T. Niu, and X. M. Wang, "The force-restoring model of corroded reinforced concrete members with flexure and compression," Journal of Xi'an University of Architecture and Technology, vol. 37, no. 2, pp. 155-159, 2005, in Chinese.

[19] J. X. Gong, J. B. Li, and G. F. Zhao, "Restoring force model of corroded reinforced concrete elements," China Civil Engineering Journal, vol. 38, no. 11, pp. 38-44, 2005, in Chinese.

[20] Q. X. Shi, D. T. Niu, and G. Y. Yan, "Experimental research on hysteretic characteristics of corroded R. C. members with flexural and compressive axial loads under repeated horizontal loading," Earthquake Engineering and Engineering Vibration, vol. 20, no. 4, pp. 44-50, 2000, in Chinese.

[21] O. Jinping, H. Zheng, W. Bin, and Q. Fawei, "Seismic damage performance-based design of reinforcement concrete structures," Earthquake Engineering and Engineering Vibration, vol. 19, no. 1, pp. 21-30, 1999, in Chinese.
[22] Y. L. Hui, Z. S. Lin, and R. Li, "Experimental study and analysis on the property of corroder experimental study and analysis on the property of corrode rebar," Industrial Construction, vol. 27, no. 6, pp. 10-13, 1997, in Chinese.

[23] H. S. Lee, T. Noguchi, and F. Tomosawa, "FEM analysis for structural performance of deteriorated RC structures due to rebar corrosion," in Proceeding of the Second International Conference on Concrete Under Severe Conditions, pp. 327-336, Tromsø, Norway, June 1998.

[24] A. A. Torres-Acosta, S. Navarro-Gutierrez, and J. TeranGuillen, "Residual flexure capacity of corroded reinforced concrete beams," Engineering Structures, vol. 29, no. 6, pp. 1145-1152, 2007.

[25] A. A. Torres-Acosta, M. J. Fabela-Gallegos, A. Muñoz-Noval, D. Vázquez-Vega, J. R. Hernandez-Jimenez, and M. MartínezMadrid, "Influence of corrosion on the structural stiffness of reinforced concrete beams," Corrosion, vol. 60, no. 9, pp. 862-872, 2004.

[26] A. A. Torres-Acosta, M. Martínez-Madrid, and A. MuñozNoval, "Remaining structural capacity of concrete beams with localized corrosion of the embedded reinforcing steel," Materiales de Construcción, vol. 53, no. 271-272, pp. 125-133, 2003.

[27] A. A. Torres-Acosta and M. Martínez-Madrid, "Residual life of corroding reinforced concrete structures in marine environment," Journal of Materials in Civil Engineering, vol. 15, no. 4, pp. 344-353, 2003.

[28] X. M. Xue, Research of Seismic Performance and Hysteretic Mode of Corroded Reinforced Concrete Members, Xi'an University of Architecture and Technology, Xi'an, China, 2003, in Chinese. 


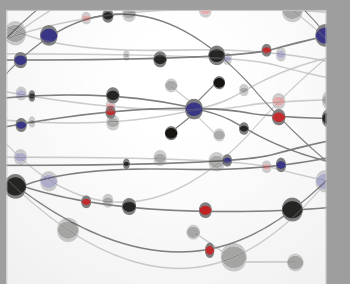

The Scientific World Journal
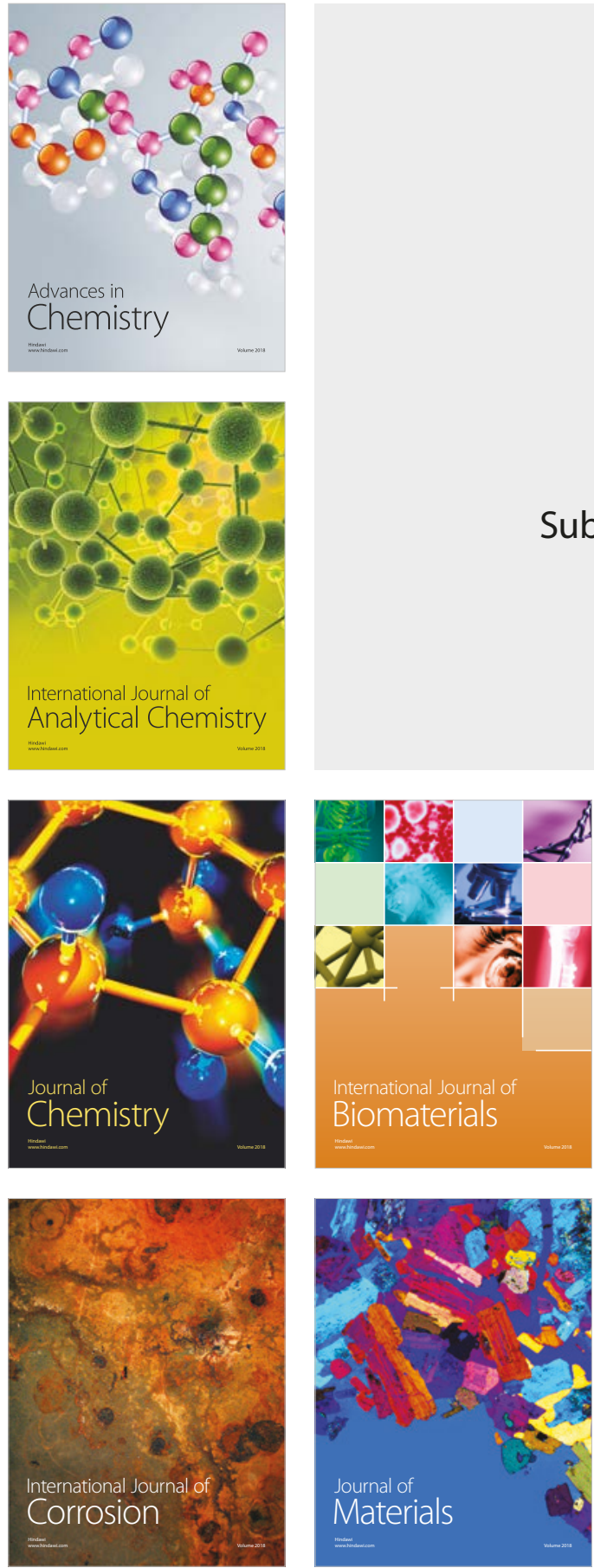

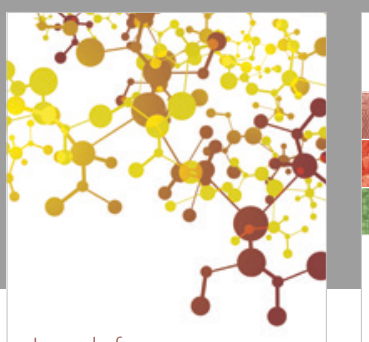

Journal of

Applied Chemistry
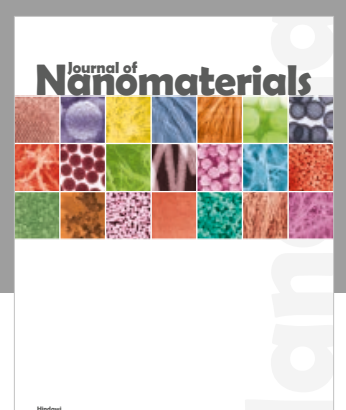

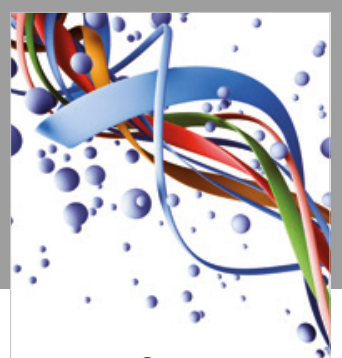

Scientifica

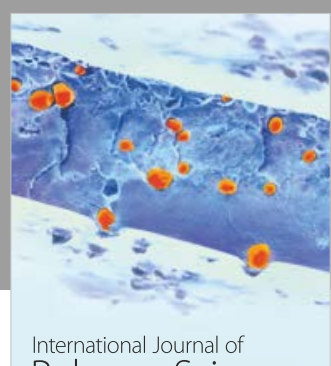

Polymer Science

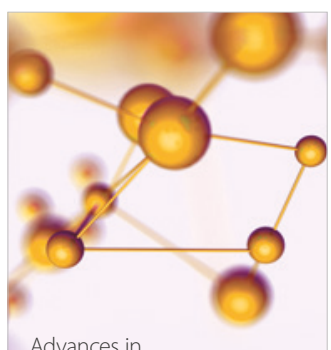

Physical Chemistry
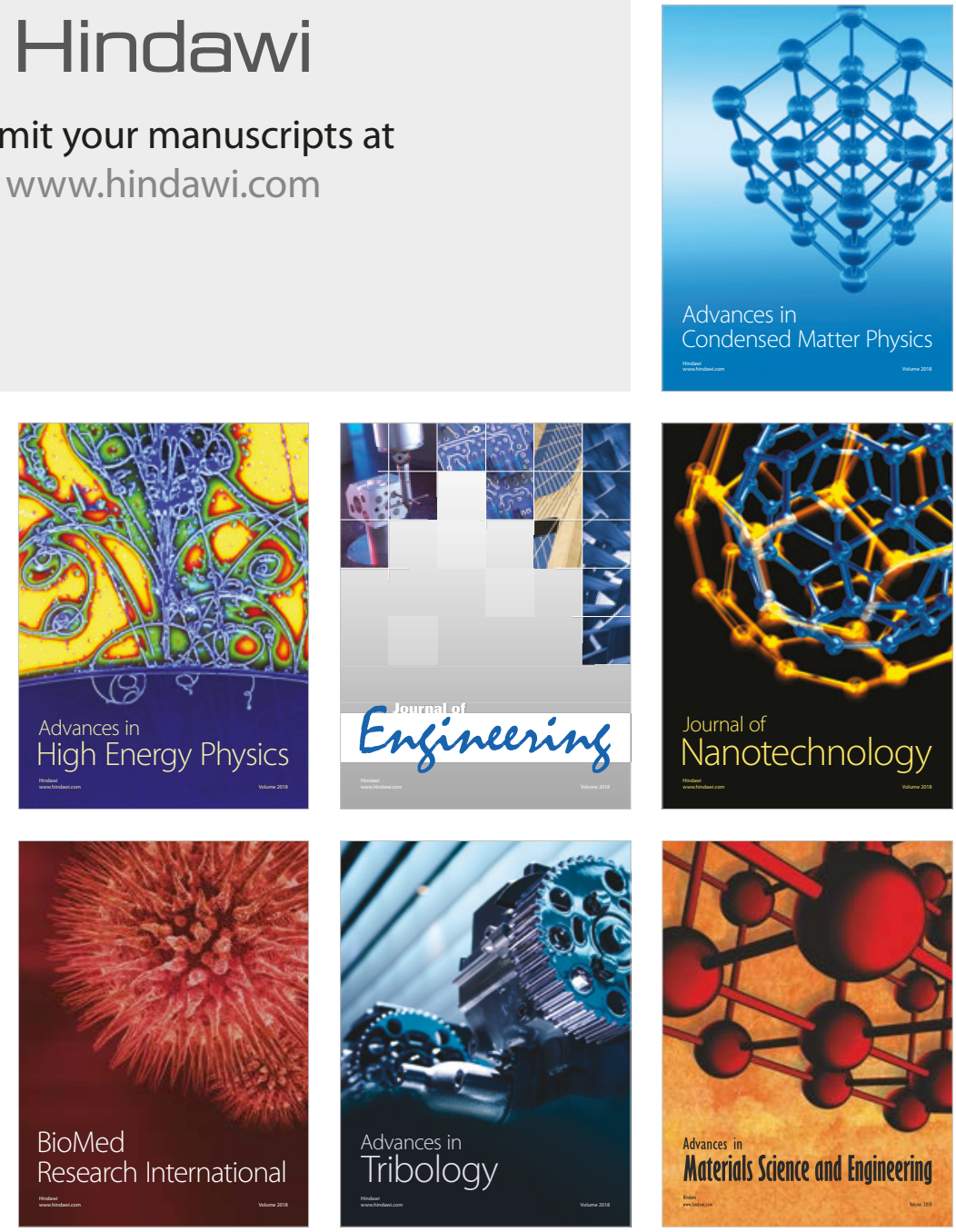